\title{
24-Hour Measurement of Gastric pH in Rural South Africa
}

\author{
Alastair M. Sammon, Eugene J. Ndebia, Ekambaram Umapathy, and Jehu E. Iputo \\ Department of Physiology, School of Medicine, Walter Sisulu University, Private Bag X1, Mthatha, Eastern Cape 5100, South Africa
}

Correspondence should be addressed to Alastair M. Sammon; alastair.sammon@gmail.com

Received 14 August 2014; Revised 20 February 2015; Accepted 28 February 2015

Academic Editor: Stephen O'Keefe

Copyright (C) 2015 Alastair M. Sammon et al. This is an open access article distributed under the Creative Commons Attribution License, which permits unrestricted use, distribution, and reproduction in any medium, provided the original work is properly cited.

\begin{abstract}
Background. Previous studies have established norms of 24-hour gastric $\mathrm{pH}$ profiles for western countries. This study was designed to establish the pattern for a rural African population with a high incidence of oesophageal cancer. Methods. After lower oesophageal manometry a probe was placed $10 \mathrm{~cm}$ distal to the lower oesophageal sphincter. We carried out 24-hour ambulatory monitoring of gastric $\mathrm{pH}$ on 59 healthy subjects. This was satisfactorily completed on 26 female and 18 male (age 21-64, median 35) subjects in the Transkei region of South Africa. Results. The mean 24 hour gastric $\mathrm{pH}$ was 2.84 and the mean night-time $\mathrm{pH}$ was 3.7. 40 volunteers recorded a night-time $\mathrm{pH}$ reaching over 4.33 volunteers recorded a night-time $\mathrm{pH}$ over 7 . Night-time alkalinisation was present for 136.4 minutes (25th centile 22.8 , 75 th centile 208.1 ) at $\mathrm{pH} 4$ or over, and $79.3(2.5,122.7)$ minutes at $\mathrm{pH} 7$ or over. Episodes of rapid alkaline rise were $17(10,47)$. 21.1\% of these occurred while supine. 35 of 36 tested subjects were positive for $H$. pylori IgG. Conclusion. Gastric alkalinisation is common in Transkei, at a higher $\mathrm{pH}$ than that reported in other studies, and is sustained longer. Nighttime alkalinisation is frequent. This suggests a high level of duodenogastric reflux.
\end{abstract}

\section{Introduction}

Transkei, part of the Eastern Cape of South Africa, is one of the three areas of the world with a very high reported incidence of squamous cancer of the oesophagus $[1,2]$. There is as yet no universally accepted mechanism of causation in these areas, though many theories have been put forward [3-7].

We have demonstrated in previous studies that the upper gastrointestinal tract in Transkei differs in some indices from published norms [8-10], and these differences may be related to oesophageal carcinogenesis. This study was designed to establish the prevalent pattern of gastric $\mathrm{pH}$ over 24 hours within this community.

\section{Methods}

We obtained permission for the study from the Research Committee of Walter Sisulu University (reference 00011A04 ). We recruited volunteers from healthy adult inhabitants of the area surrounding Canzibe Hospital in the rural Transkei region of the Eastern Cape. They were selected using a selfexclusion questionnaire and not based on diet, education, or income. Those with upper gastrointestinal complaints were eliminated. Healthy volunteers aged between 18 and 65 years with no past medical history of digestive disease or associated symptoms, diabetes, or neurological disease were recruited. None were consuming drugs at the time of the investigation.

We recorded height and weight and calculated BMI. We measured gastric pH using an antimony electrode. The lower oesophageal sphincter was defined using a pressure transducer (Gaeltec, model ICT/B) using the station pull through technique. The upper border of the sphincter was defined by a sudden increase of pressure compared to the esophageal body. Participants with no detectable LES with this technique were excluded from the study. The test was initiated after an overnight fast. After location of the lower oesophageal sphincter by manometry, the probe was passed and the electrode was positioned $10 \mathrm{~cm}$ below the sphincter. It was secured to the nose and face and connected to the recording device. We instructed the subject on how to record meal times and supine episodes, and the participant was then allowed to go home for the 24 hours of the study.

Gastric $\mathrm{pH}$ was sampled 50 times per second. Data was recorded in an Ohmega ambulatory $\mathrm{pH}$-impedance recorder and downloaded to a computer at the end of the recording period. We carried out analysis visually and also using MMS 
software version 8.19 (Medical Measurements Systems B.V., Netherlands).

We excluded meal times from analysis. We defined a rapid alkaline rise as a rise in less than 10 seconds from a baseline of $\mathrm{pH} 2$ or less to a $\mathrm{pH}$ of 4 or more. Nighttime was taken as midnight to $6 \mathrm{am}$. We defined a nighttime $\mathrm{pH}$ of greater than 4 as nighttime alkalinisation and recorded the total lengths of time over $\mathrm{pH} 4$ and over $\mathrm{pH} 7$.

We measured rapid alkaline rises visually. Other measures were provided by the software analysis programme.

We measured H. pylori serology using Helicobacter pylori IgG Elisa Kit (EIA3484, DRG International Inc.). This was carried out as a secondary investigation on all volunteers who were then available ( $80 \%$ of volunteers).

We expressed nonparametric data as median, 25th and 75th centiles.

\section{Results}

59 subjects were studied. 15 records were unusable because of a recording of less than 23 hours (one), technical faults with the recording device (five), probe misplacement (one), and poorly recorded meal or supine periods (eight). Recording times of the remaining 45 were 24 hours ( 43 records), 23 h53 and 23h30. 44 subjects had a minimum intragastric $\mathrm{pH}$ of 1.1 or less. One had a minimum $\mathrm{pH}$ of 4.0 and was eliminated from the study. 26 were female and 18 were male. Median BMI was 25.3 (range of 17.9 to 40.3 ). 35 of 36 subjects analysed for H. pylori IgG were positive.

Figure 1 shows an aggregated hourly gastric $\mathrm{pH}$ for the 44 subjects. The mean 24-hour gastric $\mathrm{pH}$ was 2.84 . The mean nighttime $\mathrm{pH}$ was 3.7 (see Table 1 and Figure 1).

There were many episodes of nighttime alkalinisation (NTA) with plateaux of up to 9-hour duration. These were not related to food or liquid ingestion. 40 subjects recorded a nighttime $\mathrm{pH}$ reaching over 4 and 33 recorded a $\mathrm{pH}$ over 7 . In 27 subjects, a nighttime $\mathrm{pH}$ of over 7 was present for over one hour and in 12 cases for over 2 hours (see Table 1 and Figure 2).

17 subjects achieved a $\mathrm{pH}$ of over 8 , with a range of duration of 6 seconds up to 130 minutes. Figure 2 shows examples of nighttime alkaline plateaux. The median time in NTA $\mathrm{Ph}>7$ for all 44 volunteers was 96.3 minutes. Including only those (33) who did have NTA $>7$, the median time was 107.1 minutes.

Rapid rises of gastric $\mathrm{pH}$ are as demonstrated in Figure 3 and the numbers are tabulated in Table 1 . Occurrences were $17(10,47) .15 .5 \%$ occurred in the first hour of recording. $21.1 \%$ occurred with the subject supine.

\section{Discussion}

Probe placement is critical, with different $\mathrm{pH}$ patterns evident in various zones of the stomach [11]. $10 \mathrm{~cm}$ distal to the lower oesophageal sphincter, as used in this study, is described as midgastric or in the corpus [12-14] and is a standard measuring position. This site is moderately influenced by antral fluid. The $\mathrm{pH}$ is reproducible over a 24 -hour period [13]. Placement $5 \mathrm{~cm}$ distal to the lower oesophageal sphincter
TABLE 1

\begin{tabular}{|c|c|}
\hline \multicolumn{2}{|l|}{ 24-hour and daytime $\mathrm{pH}$ results } \\
\hline Mean 24-hour gastric $\mathrm{pH}$ & 2.84 \\
\hline Lowest $\mathrm{pH}$ achieved (range of 0 to 4 ) & $0.5(0.2,0.6)$ \\
\hline $\begin{array}{l}\text { Percentage of time gastric } \mathrm{pH}>4 \text { (range of } \\
0.4 \text { to } 65.9 \text { ) }\end{array}$ & $22.2(13.9,33.7)$ \\
\hline $\begin{array}{l}\text { Percentage of time supine } \mathrm{pH}>4 \text { (range of } 0 \\
\text { to } 71 \text { ) }\end{array}$ & 26 \\
\hline $\begin{array}{l}\text { Percentage of time gastric } \mathrm{pH}>7 \text { (range of } 0 \\
\text { to } 37.4 \text { ) }\end{array}$ & $7.6(0.6,12.9)$ \\
\hline Mean daytime gastric $\mathrm{pH}$ & 2.67 \\
\hline \multicolumn{2}{|l|}{ Nighttime $\mathrm{pH}$ results (12 midnight to 6 am) } \\
\hline Mean nighttime gastric $\mathrm{pH}$ & 3.7 \\
\hline $\begin{array}{l}\text { Nighttime minutes } \mathrm{pH}>4 \text { (range of } 0 \text { to } \\
359.6 \text { ) }\end{array}$ & $136.4(22.8,208.1)$ \\
\hline $\begin{array}{l}\text { Nighttime minutes } \mathrm{pH}>7 \text { (range of } 0 \text { to } \\
\text { 287.1) }\end{array}$ & $79.3(2.5,122.7)$ \\
\hline
\end{tabular}

Rapid alkaline rises

(Rises in less than 10 seconds from a baseline of $\mathrm{pH} 2$ or less, to a $\mathrm{pH}$ of 4 or more)

Rapid alkaline rises in 24 hours (range of 0 to 390 )

$17(10,47)$

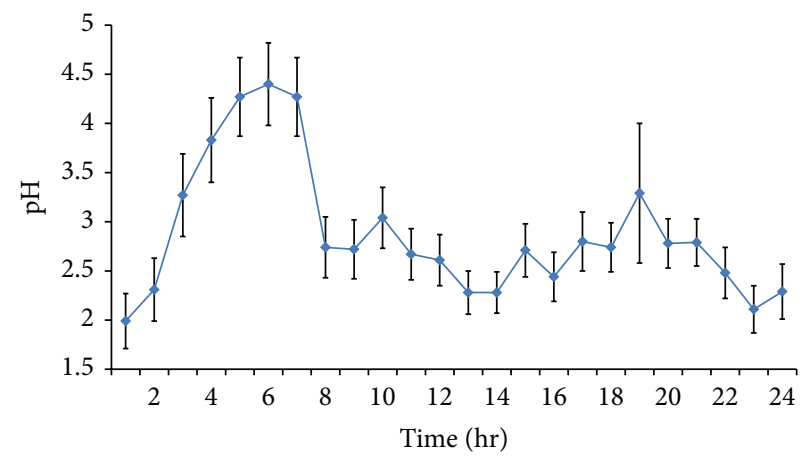

FIGURE 1: Aggregated $24 \mathrm{hr}$ gastric $\mathrm{pH}$ ( \pm one standard deviation) of 44 subjects (starting at midnight).

has been used in some studies [11,15] and produces results less influenced by the antral content and distinct from midgastric results [11].

There were a relatively high number of unsatisfactory recordings. Reasons include the physical stress on the device and its cables being used in a rural setting where subjects must continue their daily living. Lack of familiarity with using electronic devices may account for the high number of failures to record meals and supine periods. While the study was successful, the number of recording failures underlines the difficulties of such a study in rural Africa. Several reported studies have included 35 or 36 volunteers [16-18]. Closure of this study at a total of 44 successful subjects provided data comparable with these studies.

We found a higher than usual mean gastric $\mathrm{pH}$. The hourly gastric $\mathrm{pH}$ for the 24-hour period is continuously over 2. Other published graphs of composite or multiple subjects' 
TABLE 2: Other studies of healthy subjects.

\begin{tabular}{|c|c|c|c|c|c|c|}
\hline Authors & Tutuian et al. [16] & Hartmann et al. [24] & Piccoli et al. [18] & Huang et al. [23] & Roman et al. [22] & This study \\
\hline Female/male & $20 / 16$ & $0 / 20$ & $19 / 17$ & $0 / 74$ & $6 / 6$ & $26 / 18$ \\
\hline Country & USA & Germany & Switzerland & Canada & France & South Africa \\
\hline $\mathrm{HP}+\mathrm{ve}$ & Not stated & 7 of $20+v e$ & Not stated & Not stated & Not stated & 35 of 36 \\
\hline Mean/median $24 \mathrm{hr} \mathrm{pH}$ & 2.05 & 1.4 & 1.3 & 2.39 & & 2.84 \\
\hline Median daytime $\mathrm{pH}$ & 2.8 & & & & & 2.67 \\
\hline Median nighttime $\mathrm{pH}$ & 1.38 & & & & & 3.7 \\
\hline Nighttime $\mathrm{pH}>4$ & $8.14 \%$ & & & & & $9.40 \%$ \\
\hline $24 \mathrm{hr} \mathrm{pH}>4$ & $20.03 \%$ & & $8.80 \%$ & & $14.50 \%$ & $22.20 \%$ \\
\hline Supine time $\mathrm{pH}>4$ & & & & & $4.40 \%$ & $26 \%$ \\
\hline
\end{tabular}
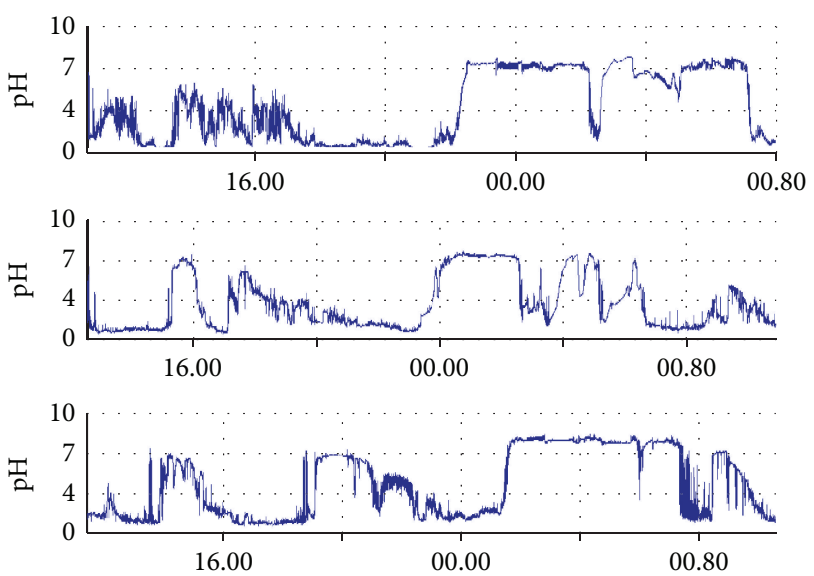

Figure 2: Samples of records with prolonged nighttime alkalinisation.

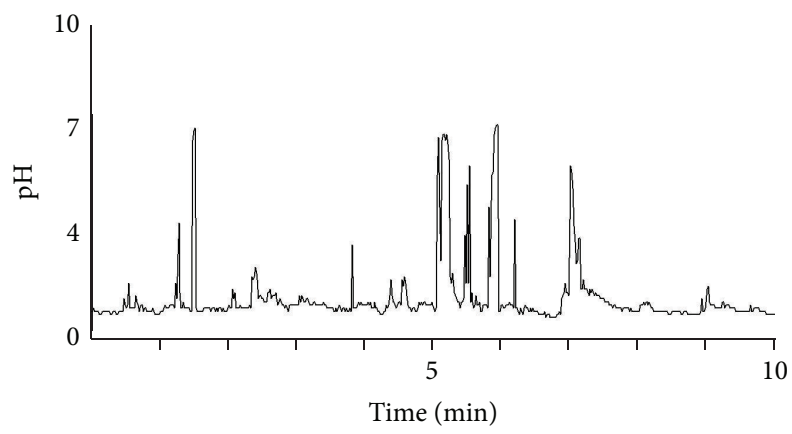

FIGURE 3: Sample of a record with rapid alkaline rises.

hourly $\mathrm{pH}$ recordings show that it is mostly between $\mathrm{pH} 1$ and $\mathrm{pH} 2[13,19]$. Published representative graphs of single subjects $[15,20,21]$ also show a baseline $\mathrm{pH}$ between 1 and 2 . Studies with mean or median gastric $\mathrm{pH}$ are shown in Table 2 and include figures from $\mathrm{pH} 1.3$ to $\mathrm{pH} 2.39$ [16, 18, 22-24].

We found a prolonged nighttime rise in $\mathrm{pH}$ compared to other studies [13-15, 19, 20,25], whose subjects showed brief periods of alkalinisation which were normally followed by a return to acidic $\mathrm{pH}$. Published figures for total time at $>\mathrm{pH} 4$ are $8.8 \%$ to $20.03 \%[12,16,17,22,26]$ (see Table 2 ).
Ours, at $22.2 \%$, is higher than all but only a little higher than the last value. However Roman et al. [22] recorded a supine $\mathrm{pH}>4,4.4 \%$ of the time, compared with $26 \%$ in our study. In summary, daytime $\mathrm{pH}$ and 24-hour profile are slightly raised compared with similar studies in North America/Europe. Nighttime and supine $\mathrm{pH}$ are more markedly raised and clearly different from other published series.

This study had two measures compatible with duodenogastric reflux (DGR). First, the presence of rapid rises in $\mathrm{pH}$ which were not associated with food intake. The rapid alkaline rises described have no adequate explanation apart from brief episodes of DGR. The occurrence of DGR is regarded as a normal event; however, we were not able to find sufficient published evidence to compare the rapid rises we found with other studies. There was a disproportionate number (15.5\% of the 24 -hour total) of rapid alkaline rises in the first hour after probe insertion, and this may reflect lowgrade retching or gagging associated with reflux as the patient accommodated to the probe; alternatively the rapid alkaline rises in this first phase may be associated with the fasting state.

The second possible measure of DGR is prolonged nonacid $\mathrm{pH}$ in the stomach. An episode of raised intragastric $\mathrm{pH}$ unrelated to food ingestion has not generally been accepted as adequate evidence on its own of DGR. Verdu et al. [27] concluded from their study that periods of high antral $\mathrm{pH}$ are often due to swallowed saliva, secretion of bicarbonate by the antral mucosa, and sequestration of the probe in the gastric mucosa. Marshall et al. [26] added to this a combination of DGR and a reduction in meal-stimulated acid production occurring towards the end of the night. Verdu et al's conclusion of the unreliability of $\mathrm{pH}$ evidence on its own is possibly biased by their use of $\mathrm{pH} 3$ as the alkaline threshold [27]. $\mathrm{pH}>4$ is more frequently used as the threshold for gastric alkaline shift [14, 26, 27]. Brown et al. [28] used a threshold $\mathrm{pH}$ of $>4$ and found a sensitivity of $84 \%$ for DGR compared with bile or amylase concentration. Fuchs et al. [29] developed a 16-variable computer programme which could reliably identify DGR using intragastric $\mathrm{pH}$ alone.

A normal pattern in other series is of nighttime alkaline peaks of $\mathrm{pH} 4-\mathrm{pH} 7$ lasting a few minutes to about an hour $[11,20]$, best demonstrated in the antrum. $46 \%$ of DGR episodes progress proximally to the fundus [14]. Barlow et al. [11] presumed these waves of alkalisation were due to 
DGR since there was no evidence of parietal cell rest in the proximal stomach during these episodes. Furthermore the rapid change and progression proximally in the stomach does not fit with other proposed explanations which include swallowed saliva, secretion of bicarbonate by the antral mucosa, or sequestration of the probe in the gastric mucosa. Björnsson and Abrahamsson [30], measuring antroduodenal pressures and gastric $\mathrm{pH}$, concluded that nocturnal $\mathrm{pH}$ rises in the antrum are caused by duodenal retroperistalsis. The common occurrence in this study, of extensive nighttime alkaline plateaux including many prolonged episodes over pH7, and up to 9-hour duration supports the contention that there is a comparatively high level of DGR in this community. There is as yet no other data from Africa to indicate whether the DGR shown in this study is within normal limits for an African rural population.

All but one of the volunteers was positive for $H$. pylori IgG.

One volunteer was achlorhydric, and therefore her data was not included for analysis. The minimum $\mathrm{pH}$ obtained for the remaining volunteers was all 1.1 or less. Positive serology does not prove current infection; however, acid production may have been reduced by chronic $H$. pylori infection of the corpus. Tsai et al. [31] showed a rise in median $\mathrm{pH}$ from control levels of $1.4 \pm 0.1$ to $\mathrm{pH} 1.6 \pm 0.3$ in those with $H$. pylori infection. Furuta et al. [32] showed much greater reductions in acid production in subjects with active duodenal or gastric ulceration. All of the final 44 volunteers of the current study demonstrated the ability to create a low intragastric $\mathrm{pH}$ at some stage during the $24 \mathrm{hr}$ period.

Most African studies report a high prevalence of $H$. pylori of $61-100 \%$ [33]. A study in Bloemfontein in South Africa [34] showed a rising prevalence during childhood, reaching $84.2 \%$ by the age of 15 . At $97 \%$, the prevalence rate in our volunteers is at the upper end of the spectrum.

Chebib et al. [35] found no correlation between the presence of $H$. pylori and enterogastric reflux; however, $H$. pylori was present more frequently in patients with positive enterogastric reflux. Nakagawara et al. [36] found that DGR facilitates the survival of $H$. pylori in the gastric stump after a gastrectomy. While there is no published evidence that H. pylori causes or facilitates DGR, the possibility must be considered that in our population the high prevalence of $H$. pylori infection is encouraged by a high level of DGR.

DGR is associated with raised intragastric $\mathrm{pH}[14,28,37]$. There is a strong positive association of raised intragastric $\mathrm{pH}$ with nonacid gastroesophageal reflux $[22,29]$. It is well established that pernicious anaemia and a postgastrectomy state are associated with reduced gastric acidity and also with squamous cancer of the oesophagus $[38,39]$.

Iijima et al. [40] demonstrated a risk for squamous cancer of the oesophagus of profound gastric hypochlorhydria after adjusting for the effect of gastric atrophy. An important question is whether a raised intragastric $\mathrm{pH}$ of a different nature compared to either achlorhydria or profound hypochlorhydria, and such as found in our volunteers, is a risk factor for squamous cancer of the oesophagus, and if so in what circumstances. The answer to this question is crucial for the community we have studied. It is also important to elucidate further the relation between enterogastric and gastroesophageal reflux.

\section{Conclusion}

Gastric alkalinisation is common in the sample population studied, at a higher $\mathrm{pH}$ than that reported in other studies of healthy subjects, and is sustained longer. Nighttime alkalinisation is particularly frequent. There is neither achlorhydria nor profound hypochlorhydria. This pattern is suggestive of a high level of duodenogastric reflux. The presence of this pattern in an area of very high risk for squamous cancer of the oesophagus requires further investigation.

\section{Conflict of Interests}

The authors declare that there is no conflict of interests regarding the publication of this paper.

\section{Acknowledgments}

This work is supported by The Jennie Marsh Trust, The South African Medical Research Council. The authors acknowledge with thanks Miss MK Nanjoh who carried out some of the investigations.

\section{References}

[1] R. Doll, "The geographical distribution of cancer," British Journal of Cancer, vol. 23, no. 1, pp. 1-8, 1969.

[2] Coordinating Group for Research on Etiology of Esophageal Cancer in North China, "The epidemiology and etiology of esophageal cancer in North China. A preliminary report," Chinese Medical Journal, vol. 1, no. 3, pp. 167-183, 1975.

[3] R. J. Burrell, "Oesophageal cancer in the Bantu," South African Medical Journal, vol. 31, no. 17, pp. 401-409, 1957.

[4] I. F. H. Purchase, R. C. Tustin, and S. J.van Rensburg, "Biological testing of food grown in the Transkei," Food and Cosmetics Toxicology, vol. 13, no. 6, pp. 639-647, 1975.

[5] S. J. van Rensburg, "Epidemiologic and dietary evidence for a specific nutritional predisposition to esophageal cancer," Journal of the National Cancer Institute, vol. 67, no. 2, pp. 243251, 1981.

[6] E. F. Rose, "Epidemiology of oesophageal cancer in Southern Africa," Advances in Medical Oncology, Research, and Education, vol. 9, pp. 317-326, 1979.

[7] W. F. O. Marasas, "Discovery and occurrence of the fumonisins: a historical perspective," Environmental Health Perspectives, vol. 109, supplement 2, pp. 239-243, 2001.

[8] A. M. Sammon and A. Morgan, "Dietary fat and salivary prostaglandin E2," Prostaglandins and Other Lipid Mediators, vol. 67, no. 2, pp. 137-141, 2002.

[9] A. M. Sammon, M. Mguni, L. Mapele, K. O. Awotedu, and J. E. Iputo, "Bimodal distribution of fasting gastric acidity in a rural African population," South African Medical Journal, vol. 93, no. 10, pp. 786-788, 2003.

[10] J. E. Iputo, A. M. Sammon, L. Mapele, and K. O. Awotedu, "Gastric luminal epidermal growth factor is affected by diet," South African Medical Journal, vol. 94, no. 12, pp. 969-971, 2004. 
[11] A. P. Barlow, R. A. Hinder, T. R. DeMeester, and K. Fuchs, "Twenty-four-hour gastric luminal $\mathrm{pH}$ in normal subjects: influence of probe position, food, posture, and duodenogastric reflux," American Journal of Gastroenterology, vol. 89, no. 11, pp. 2006-2010, 1994.

[12] D. K. Manifold, R. E. K. Marshall, A. Anggiansah, and W. J. Owen, "Effect of omeprazole on antral duodenogastric reflux in Barrett oesophagus," Scandinavian Journal of Gastroenterology, vol. 35, no. 8, pp. 796-801, 2000.

[13] T. Cilluffo, D. Armstrong, F. Castiglione et al., "Reproducibility of ambulatory gastric $\mathrm{pH}$ recordings in the corpus and antrum: effect of food, time, and electrode position," Scandinavian Journal of Gastroenterology, vol. 25, no. 10, pp. 1076-1083, 1990.

[14] S. Mattioli, V. Pilotti, V. Felice et al., "Ambulatory 24-hr $\mathrm{pH}$ monitoring of esophagus, fundus, and antrum," Digestive Diseases and Sciences, vol. 35, no. 8, pp. 929-938, 1990.

[15] H. J. Stein, R. A. Hinder, T. R. DeMeester et al., "Clinical use of 24-hour gastric $\mathrm{pH}$ monitoring vs o-diisopropyl iminodiacetic acid (DISIDA) scanning in the diagnosis of pathologic duodenogastric reflux," Archives of Surgery, vol. 125, no. 8, pp. 966-971, 1990.

[16] R. Tutuian, P. O. Katz, W. Bochenek, and D. O. Castell, "Dosedependent control of intragastric $\mathrm{pH}$ by pantoprazole, 10, 20 or $40 \mathrm{mg}$, in healthy volunteers," Alimentary Pharmacology and Therapeutics, vol. 16, no. 4, pp. 829-836, 2002.

[17] W. K. Fackler, M. F. Vaezi, and J. E. Richter, "Ambulatory gastric pH monitoring: proper probe placement and normal values," Alimentary Pharmacology and Therapeutics, vol. 15, no. 8, pp. 1155-1162, 2001.

[18] F. Piccoli, G. Ory, A. Hadengue, C. Beglinger, and L. Degen, "Effect of intravenous esomeprazole $40 \mathrm{mg}$ and pantoprazole $40 \mathrm{mg}$ on intragastric $\mathrm{pH}$ in healthy subjects: a prospective, open, randomised, two-way cross-over comparative study," Arzneimittel-Forschung, vol. 57, no. 10, pp. 654-658, 2007.

[19] V. Savarino, G. S. Mela, P. Zentilin et al., "Time pattern of gastric acidity in Barrett's esophagus," Digestive Diseases and Sciences, vol. 41, no. 7, pp. 1379-1383, 1996.

[20] H. J. Stein, T. R. DeMeester, J. H. Peters et al., "Technique, indications, and clinical use of ambulatory 24-hour gastric $\mathrm{pH}$ monitoring in a surgical practice," Surgery, vol. 116, no. 4, pp. 758-767, 1994.

[21] G. L. Shih, C. Brensinger, D. A. Katzka, and D. C. Metz, "Influence of age and gender on gastric acid secretion as estimated by integrated acidity in patients referred for 24-hour ambulatory pH monitoring," American Journal of Gastroenterology, vol. 98, no. 8, pp. 1713-1718, 2003.

[22] S. Roman, I. Serraj, H. Damon, and F. Mion, "Correlation between gastric $\mathrm{pH}$ and gastro-oesophageal reflux contents: ambulatory $\mathrm{pH}$-impedance monitoring results," Neurogastroenterology and Motility, vol. 19, no. 7, pp. 562-568, 2007.

[23] J.-Q. Huang, D. R. Goldwater, A. B. R. Thomson et al., "Acid suppression in healthy subjects following lansoprazole or pantoprazole," Alimentary Pharmacology and Therapeutics, vol. 16, no. 3, pp. 425-433, 2002.

[24] M. Hartmann, A. Ehrlich, H. Fuder et al., "Equipotent inhibition of gastric acid secretion by equal doses of oral or intravenous pantoprazole," Alimentary Pharmacology and Therapeutics, vol. 12, no. 10, pp. 1027-1032, 1998.

[25] L. Iraki, A. Bogdan, F. Hakkou, N. Amrani, A. Abkari, and Y. Touitou, "Ramadan diet restrictions modify the circadian time structure in humans. A study on plasma gastrin, insulin, glucose, and calcium and on gastric $\mathrm{pH}$," The Journal of Clinical Endocrinology \& Metabolism, vol. 82, no. 4, pp. 1261-1273, 1997.

[26] R. E. K. Marshall, A. Anggiansah, W. A. Owen, D. K. Manifold, and W. J. Owen, "The extent of duodenogastric reflux in gastrooesophageal reflux disease," European Journal of Gastroenterology and Hepatology, vol. 13, no. 1, pp. 5-10, 2001.

[27] E. F. Verdu, R. Fraser, G. M. Murphy, A. L. Blum, and D. Armstrong, "The origin of nocturnal intragastric $\mathrm{pH}$ rises in healthy subjects," Scandinavian Journal of Gastroenterology, vol. 30, no. 10, pp. 935-943, 1995.

[28] T. H. Brown, I. Holbrook, R. F. G. King, and K. Ibrahim, "24-hour intragastric $\mathrm{pH}$ measurement in the assessment of duodenogastric reflux," World Journal of Surgery, vol. 16, no. 5, pp. 995-999, 1992.

[29] K. H. Fuchs, T. R. DeMeester, R. A. Hinder, H. J. Stein, A. P. Barlow, and N. C. Gupta, "Computerized identification of pathologic duodenogastric reflux using 24-hour gastric $\mathrm{pH}$ monitoring," Annals of Surgery, vol. 213, no. 1, pp. 13-20, 1991.

[30] E. S. Björnsson and H. Abrahamsson, "Nocturnal antral pH rises are related to duodenal phase III retroperistalsis," Digestive Diseases and Sciences, vol. 42, no. 12, pp. 2432-2438, 1997.

[31] S.-H. Tsai, C.-M. Chen, C.-S. Chang, and G.-H. Chen, "Effect of Helicobacter pylori infection on intragastric acidity in patients with reflux esophagitis," Journal of Gastroenterology, vol. 39, no. 9, pp. 821-826, 2004.

[32] T. Furuta, S. Baba, M. Takashima et al., "Effect of Helicobacter pylori infection on gastric juice $\mathrm{pH}$," Scandinavian Journal of Gastroenterology, vol. 33, no. 4, pp. 357-363, 1998.

[33] I. Segal, R. Ally, and H. Mitchell, "Helicobacter pylori-an African perspective," QJM, vol. 94, no. 10, pp. 561-565, 2001.

[34] H. H. Pelser, K. C. Househam, G. Joubert et al., "Prevalence of Helicobacter pylori antibodies in children in Bloemfontein, south Africa," Journal of Pediatric Gastroenterology and Nutrition, vol. 24, no. 2, pp. 135-139, 1997.

[35] H. Chebib, V. Artiko, M. Ugljesić, M. Petrović, and V. Obradović, "The presence and significance of Helicobacter pylori in patients with enterogastric reflux," Acta Chirurgica Iugoslavica, vol. 46, no. 1-2, pp. 53-56, 1999.

[36] H. Nakagawara, K. Miwa, S. Nakamura, and T. Hattori, "Duodenogastric reflux sustains Helicobacter pylori infection in the gastric stump," Scandinavian Journal of Gastroenterology, vol. 38, no. 9, pp. 931-937, 2003.

[37] F. Dai, J. Gong, R. Zhang, J.-Y. Luo, Y.-L. Zhu, and X.-Q. Wang, "Assessment of duodenogastric reflux by combined continuous intragastric $\mathrm{pH}$ and bilirubin monitoring," World Journal of Gastroenterology, vol. 8, no. 2, pp. 382-384, 2002.

[38] A. W. Hsing, L. E. Hansson, J. K. McLaughlin et al., "Pernicious anaemia and subsequent cancer. A population-based cohort study," Cancer, vol. 71, no. 3, pp. 745-750, 1993.

[39] M. Maeta, S. Koga, H. Andachi, H. Yoshioka, and T. Wakatsuki, "Esophageal cancer developed after gastrectomy," Surgery, vol. 99, no. 1, pp. 87-91, 1986.

[40] K. Iijima, T. Koike, Y. Abe et al., "Gastric hyposecretion in esophageal squamous-cell carcinomas," Digestive Diseases and Sciences, vol. 55, no. 5, pp. 1349-1355, 2010. 


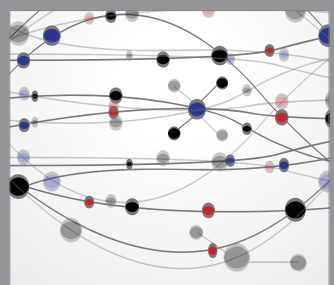

The Scientific World Journal
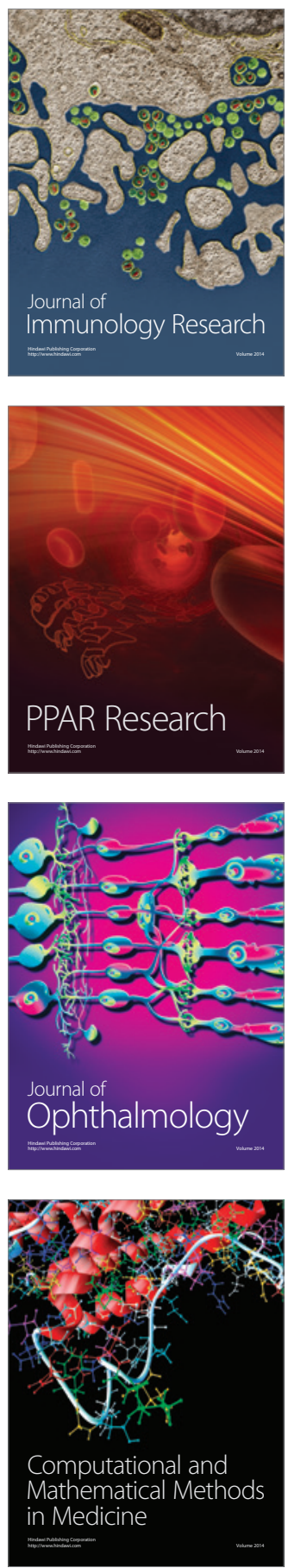

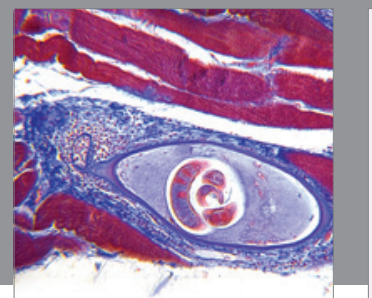

Gastroenterology

Research and Practice
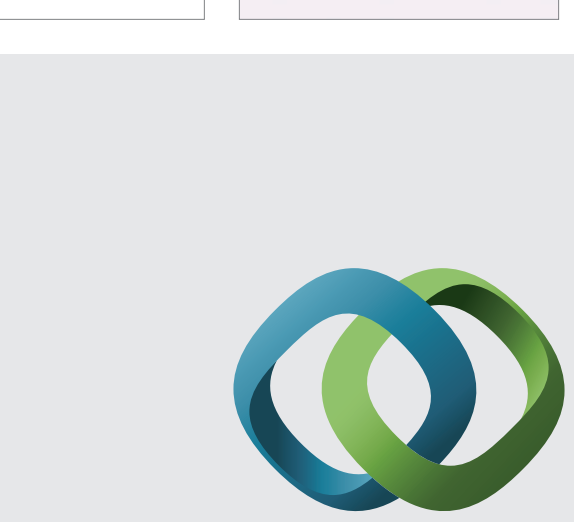

\section{Hindawi}

Submit your manuscripts at

http://www.hindawi.com
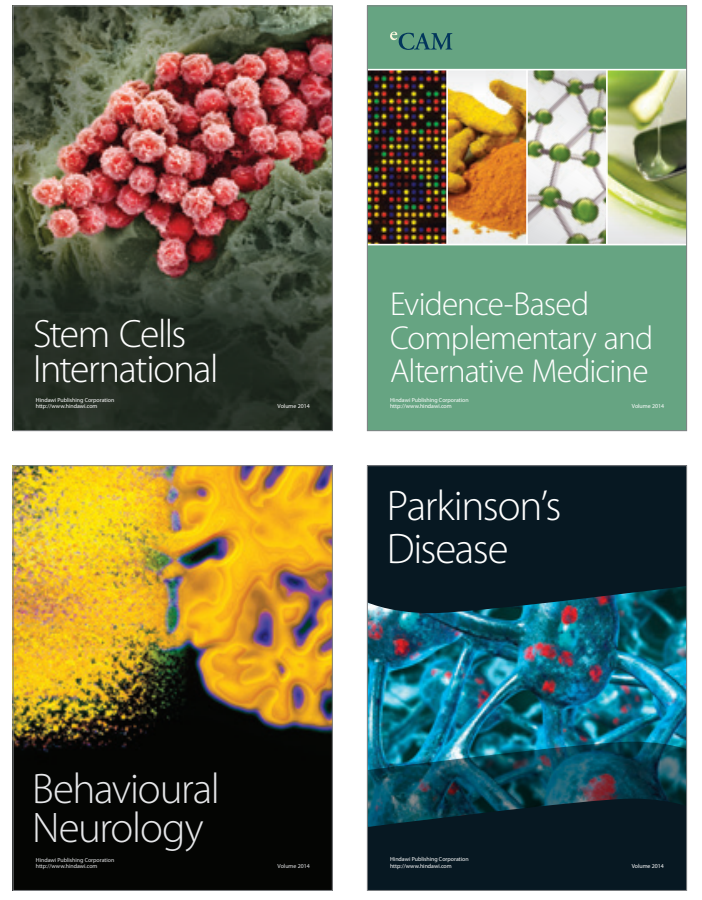
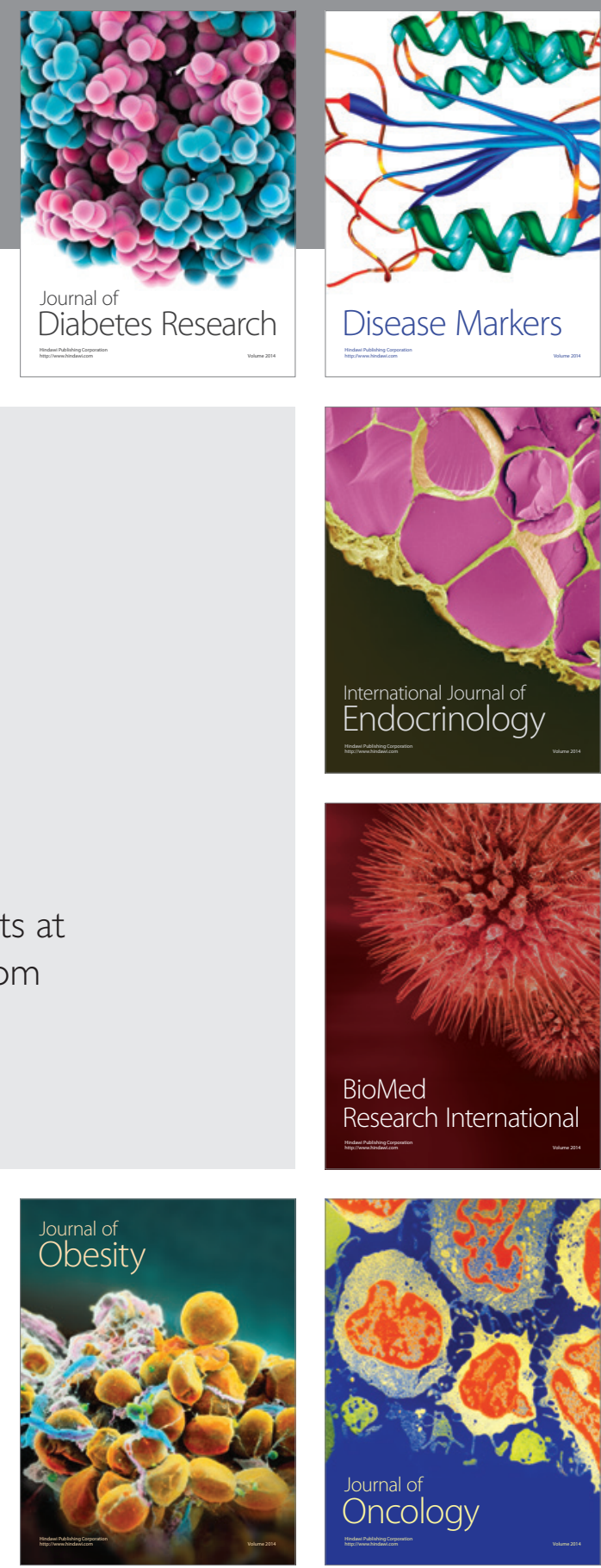

Disease Markers
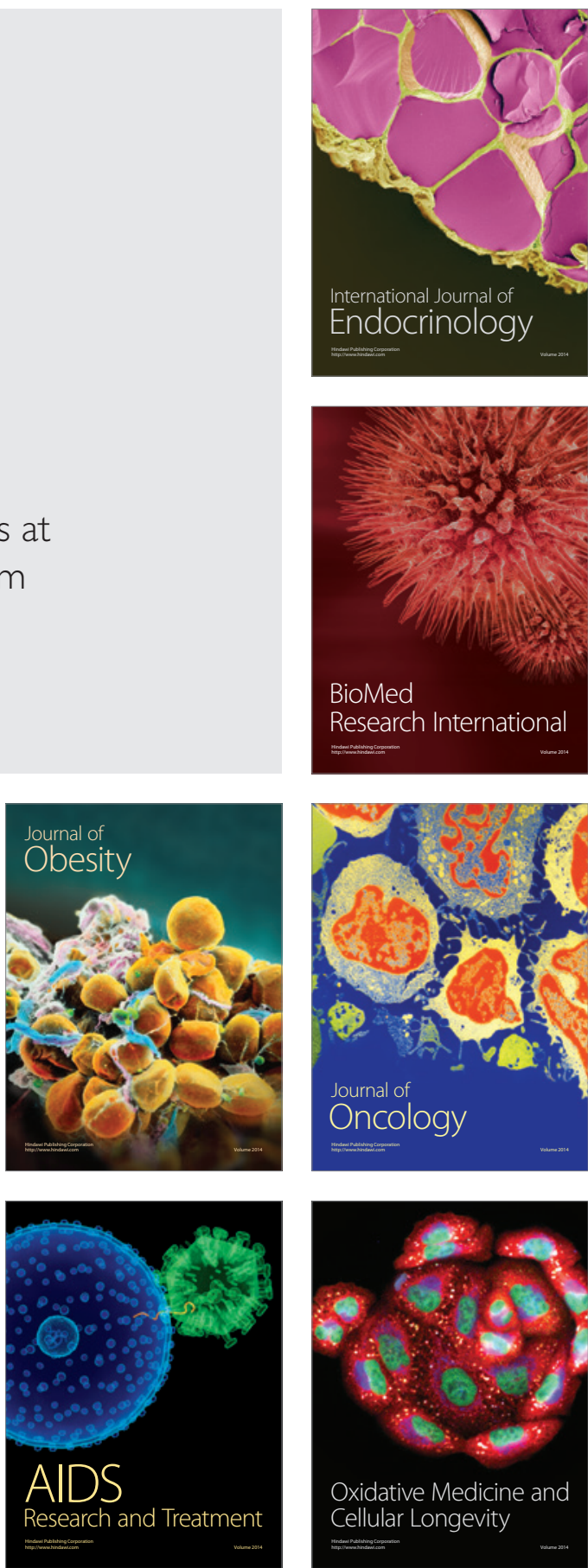